[LONDON] Suggestions for increasing the influence of the United Nations Environment Programme (UNEP) have run into strong opposition from both developing countries and the Global Environment Facility (GEF), which finances environmental projects.

GEF has objected vigorously to a proposal by Klaus Töpfer, UNEP's executive director, that UNEP should play a stronger role in shaping GEF priorities and programmes. The proposal was contained in a draft report by a high-level task force on reforming environment policy across the UN system, set up by UN Secretary General Kofi Annan and chaired by Töpfer.

In an unusually strongly worded letter, Mohamed El-Ashry, GEF's chief executive, has warned Töpfer that UNEP "might find itself on a collision course with the GEF Council" unless "some inaccurate references to the GEF" were changed. The changes, primarily concerning UNEP's role with respect to GEF, are understood to have been made.

El-Ashry wrote that the fund's governing council was "the only entity in the GEF structure" with responsibility for guiding funding. UNEP, he pointed out, was among GEF's "implementing agencies", and therefore had to be accountable to the GEF council. Other implementing agencies are the UN Development Programme and the World Bank.

This is not the first time Töpfer has met opposition to his efforts to find a new role for UNEP. Last month, developing countries

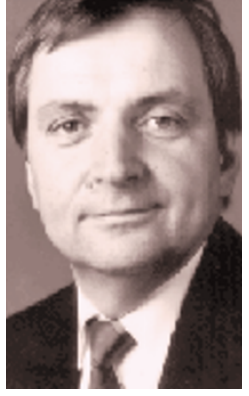

Töpfer: committed to a stronger UNEP. blocked his suggestion to set up an intergovernmental panel of experts to explore the use of economic instruments — such as a greenhouse-gas trading system to reduce emissions - to protect the environment.

Töpfer had floated this idea at a meeting of the UN climate convention's advisory body of scientific experts in Bonn. But scientists representing the Group of 77 developing countries said research into economic instruments was already dealt with by one of the working groups of the Intergovernmental Panel on Climate Change (IPCC).

Developing countries were similarly critical of an earlier Töpfer suggestion, delivered to the conference of the UN biodiversity convention in Bratislava, that UNEP could take over much of the convention's scientific work (see Nature 393, 99; 1998 ).

Töpfer now faces a dilemma. Few of his critics disagree with the need to strengthen environment policy across the UN system, but few are convinced that this should be done through UNEP, which they believe has outlived its usefulness as most of the environmental conventions and institutions it has spawned are now accountable to their own member countries.

Indeed, many countries now see greater involvement by UNEP as a form of interference. But Töpfer, an experienced German politician with more than a decade spent at cabinet level, says he remains committed to his goal of strengthening UNEP.

To that end, he repeats his desire to see non-government groups play a greater role in the decision-making process, and feels strongly that UNEP should take more responsibility for scientific assessments and environmental monitoring. "These are not just my suggestions. They are also those of the task force," he says.

Töpfer says he has learnt a lot since becoming executive director of UNEP four months ago. But he adds that he will not be distracted from his reforms, just as his predecessors remained, despite much opposition, committed to setting up the IPCC.

"They didn't say 'let's change our minds' because of the criticism,” Töpfer says. "Don't worry about the criticism. If someone is not criticized, it means he is not doing anything. We are doing things, which is why we will be criticized. But we also get applause."

The UN task force recommended setting up a new Environment Management Group comprising representatives of all relevant UN institutions and chaired by Töpfer. It also suggests reviving Earthwatch, the UN's system of gathering environmental information, set up in the 1970s.

\title{
French panel calls for closer monitoring of genetic modification
}

[PARIS] A French lay panel has delivered a mixed verdict on the use of genetically modified organisms (GMOs). It concluded that more research is needed before the risks can be properly assessed, and that greater public monitoring is required to ensure that government policy on GMOs is not unduly influenced by economic interests.

This was the outcome of France's first 'consensus conference' or conférence de citoyens, organized in Paris two weeks ago along the lines of the model invented in Scandinavia and since applied in the United Kingdom and elsewhere.

The 'jury' of 14 lay people, screened for independence from interested parties such as environmental pressure groups or foodbased industrial organizations, were coached on the subject in advance. During the conference, GMO-related issues were debated in front of them by scientists, nongovernmental organizations, industrialists and other bodies.

In its report, the jury acknowledged that GMOs have potential benefits in medicine, and supported greater research in this area.
But it also argued that research into the ecological risks of GMOs is inadequate and requires a substantial new impetus.

In particular, the panel recommended that such research should be carried out by national research agencies. "The power of public research bodies is probably the best guarantee of independence with respect to private sector research and the influence of multinationals," it said.

It called for an improvements in both the composition and the procedures of the Commission de Génie Moléculaire, the body that advises the government on approving GMOs. In the meantime, several members of the jury felt that a moratorium of the use of GMOs would be appropriate.

The dominance of multinational firms was identified as a major concern. The jury argued that this risked leaving farmers dependent on the decisions of a few large monopolies. But it thought GMOs might improve the international competitiveness of France's agricultural produce.

Commenting in the newspaper Le Figaro on the outcome of this first consensus conference, Claude Allègre, the minister for national education, research and technology, said there was a need for "a happy medium between the competence of the aristocracy and the dictatorship of ignorance". But he argued that, although caution was warranted, too much analysis could lead to paralysis. "If we had held meetings in the factories to know whether or not this or that was risky, plastic would never have been invented," he said.

The conference is widely seen as part of an effort by the government to ensure greater public consultation on technological choices, since trust in expert committees has been shaken by the recent crises over BSE and contaminated blood.

GMOs are a hot potato for socialist prime minister Lionel Jospin's government, which has provisionally authorized the cultivation of transgenic maize. The Greens, France's main ecological party, form part of his government, but agriculture is one of the largest sectors in the French economy, and those who work in the countryside are an influential block of voters.

Eric Glover 